\title{
PEMBERIAN EKSTRAK ETANOL KUBIS UNGU (Brassica Oleracea Var. Capitata L.) MENYEBABKAN KADAR MALONDIALDEHID MENJADI RENDAH DAN KADAR SUPEROKSIDA DISMUTASE MENJADI TINGGI PADA TIKUS GALUR WISTAR JANTAN (Rattus Norvegicus) YANG DIBERI LATIHAN FISIK MAKSIMAL
}

\author{
FADLI $^{1 \bullet}$, I PUTU GEDE ADIATMIKA ${ }^{2}$, I KETUT TIRTAYASA $^{2}$ \\ ${ }^{1}$ Program Studi Magister Biomedik, Fakultas Kedokteran Universitas Udayana \\ ${ }^{2}$ Departemen Ilmu FAAL, Fakultas Kedokteran, Universitas Udayana
}

\begin{abstract}
Abstrak: Aktivitas fisik maksimal memicu terjadinya peningkatkan produksi peroksidasi lipid yang ditandai dengan terbentuknya malondialdehyde (MDA) dan dapat menurunkan aktivitas enzim superoksida dismutase (SOD). Penggunaan antioksidan dari tumbuhan seperti kubis ungu yang mengandung senyawa flavonoid menjadi salah satu alternatif untuk menetralisir terjadinya peningkatan malondialdehyde (MDA) dan penurunan superoksida dismutase (SOD). Penelitian ini dilakukan dengan menggunakan metode eksperimental dengan post-test control group design dengan binatang coba 32 ekor tikus galur wistar (Rattus norvegicus) jantan, berumur 2-3 bulan, dengan berat badan 200 gram. Hasil penelitian menunjukkan bahwa perbandingan jumlah rerata kadar malondialdehyde (MDA) pada kelompok kontrol (P0) adalah 1,568 $\pm 0,425$ $\mu \mathrm{M}$ dan pada kelompok perlakuan (P1) adalah 1,066 $\pm 0,365 \mu \mathrm{M}(\mathrm{p}<0,001)$. Rerata jumlah kadar SOD pada

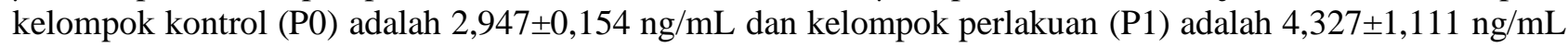
kedua hasil ini berbeda bermakna ( $<0,000)$. Hasil ini menunjukan bahwa pemberian ekstrak kubis ungu (Brassica oleraceavar. capitata L.) pada tikus galur wistar (Rattus norvegicus) jantan dapat menyebabkan kadar malondialdehyde (MDA) lebih rendah dan dapat menyebabkan kadar superoksida dismutase (SOD) lebih tinggi secara bermakna ( $\mathrm{p}$ 0,05). Disimpulkan bahwa pemberian ekstrak etanol kubis ungu pada tikus galur wistar jantan dapat menyebabkan kadar malondialdehyde (MDA) lebih rendah dan dapat menyebabkan kadar superoksida dismutase (SOD) lebih tinggi pada tikus galur wistar jantan yang diberi latihan fisik maksimal selama 14 hari.
\end{abstract}

Kata kunci: kubis ungu, latihan fisik maksimal, malondialdehid (MDA), superoksida dismutase (SOD)

Abstract: Maximum physical activity triggers an increase in lipid peroxidation production, which is characterized by the formation of malondialdehyde (MDA) and can reduce the activity of the enzyme superoxide dismutase (SOD). The use of antioxidants from plants such as purple cabbage containing flavonoid compounds is an alternative way to neutralize the increase in malondialdehyde (MDA) and a decrease in superoxide dismutase (SOD) levels. An experimental study using a post-test control group design was conducted among 32 male Wistar rats (Rattus norvegicus), aged 2-3 months, with a bodyweight of 200 grams. The results showed that the mean level of malondialdehyde (MDA) in the group control (P0) was $1.568 \pm$ $0.425 \mu \mathrm{M}$ and in the group experiment (P1) was $1.066 \pm 0.365 \mu \mathrm{M}$ there two results significant different (p $<0.001$ ). In addition, the mean levels of SOD in the group control (P0) was $2.947 \pm 0.154 \mathrm{ng} / \mathrm{mL}$ and the group experiment (P1) was $4.327 \pm 1.111 \mathrm{ng} / \mathrm{mL}$ ( $\mathrm{p}<0.000$ ). Administration of the purple cabbage extract (Brassica oleraceavar. Capitata L.) in male Wistar strain rats (Rattus norvegicus) significantly reduced malondialdehyde (MDA) level and increased superoxide dismutase (SOD) $(\mathrm{p}<0,05)$ Which was induced by physical exercise for a maximum of 14 days.

Keywords: malondialdehyde (MDA), maximum physical exercise, purple cabbage, superoxide dismutase (SOD)

\section{PENDAHULUAN}

Stres oksidatif merupakan suatu kondisi ketidakseimbangan antara produksi radikal bebas dengan antioksidan di dalam tubuh sehingga memicu kondisi patologis seperti penuaan, inflamasi, penyakit kardiovaskular, neurodegeneratif dan kanker. Keterkaitan antara latihan fisik dan stres oksidatif sangat tergantung pada intensitas dan durasinya.

Atlet profesional sering kali melakukan latihan fisik melebihi yang dianjurkan apalagi saat menghadapi kompetisi, dalam jangka panjang intensitas latihan yang meningkat ini tentunya sangat merugikan dan dapat menimbulkan efek negatif salah satunya yaitu meningkatkan senyawa oksidan dalam tubuh (Yavari et al., 2015).

•email korespondensi: sdoni1878@gmail.com 
Pelatihan fisik berlebih meningkatkan reactive oxygen species (ROS) dalam jaringan, dan $2-5 \%$ oksigen yang dipakai dalam metabolisme tereduksi menjadi ion superoksid yang bersifat radikal bebas. Pelepasan radikal bebas akan terlibat dalam proses oksidasi lemak membran sel otot, yang disebut peroksidasi lipid dan menyebabkan sel menjadi lebih mudah mengalami proses penuaan atau kerusakan lain (Tarnajaya et al., 2018).

Kondisi stres oksidatif akan menyebabkan radikal bebas memperoksidasi lipid membran sel dan merusak organisasi membran sel. Biomarker terjadinya stres oksidatif adalah tingginya kadar malondialdehyde (MDA) dan menurunnya aktivitas superoksida dismutase (SOD) akibat proses peroksidasi lipid yang berlebihan di dalam sel (Hu et al., 2014). Malodialdehyde (MDA) merupakan senyawa toksik hasil akhir terputusnya rantai karbon asam lemak pada proses peroksidasi lipid. Proses oksidasi lipid ini merupakan salah satu hasil kerja dari radikal bebas yang diketahui paling awal dan paling mudah pengukurannya (Winarsih, 2007).

Tubuh secara alami mempunyai kemampuan untuk menangkal radikal bebas dengan membentuk antioksidan endogen pada saat level ROS meningkat, yang kadarnya dapat diukur melalui glutation peroxidase (GPX), katalase dan aktivitas enzim superoxide dismutase (SOD). Aktivitas fisik yang terlalu tinggi akan mengakibatkan kadar radikal bebas dalam tubuh juga meningkat sehingga antioksidan endogen tidak mampu untuk menetralisir radikal bebas, dibutuhkan antioksidan eksogen dalam jumlah yang lebih banyak untuk menetralisir efek radikal bebas (Astuti 2008). Superoxide dismutase (SOD) yang merupakan sistem pertahanan tubuh garis pertama terhadap aktivasi reactive oxygen species (ROS) (Wulandari, 2016).

Mengatasi stress oksidatif dalam tubuh diperlukan antioksidan dari luar. Salah satu sumbernya adalah tanaman yang mengandung antioksidan. Tanaman Kubis Ungu (Brassica oleracea var. capitata $L$.) memiliki potensi sebagai sumber antioksidan (Pratama, 2018), menyatakan hasil skrining fitokimia tersebut, dalam simplisia kubis ungu dan ekstrak etanol kubis ungu mengandung golongan senyawa seperti flavonoid, glikosida, dan antrakinon (Harahap, 2016).

Flavonoid memiliki potensi sebagai penghambat, radikal bebas baik secara langsung maupun tidak langsung. Secara langsung, gugus hidroksil yang terikat pada cincin aromatik dapat mendonorkan atom hidrogen kepada radikal bebas serta mengkhelat logam untuk menghambat proses peroksidasi lemak (Pietta, 2000). Secara tidak langsung, flavonoid dapat meningkatkan ekspresi gen antioksidan endogen (Sumardika dan Jawi, 2012).

Berdasarkan penetilian terdahulu yang dilakukan oleh Pratama. (2018) tentang Efektifitas pemanfaatan potensi senyawa fenolik kubis ungu (brassica oleraceae var.carpitata. L) secara instrumen uv-vis menunjukan bahwa pada kubis ungu terdapat senyawa fenol dan flavonoid yang dapat berfungsi sebagai antioksidan. Belum ada penelitian tentang pengaruh pemberian ekstrak etanol kubis ungu terhadap kadar malodialdehyde (MDA) dan superoksida dismutase (SOD) plasma tikus yang diberikan latihan fisik maksimal sehingga diperlukan penelitian untuk mengetahui pemberian ekstrak etanol kubis ungu apakah dapat menyebabkan kadar malodialdehyde (MDA) menjadi rendah dan apakah dapat menyebabkan kadar superoksida dismutase (SOD) menjadi tinggi pada tikus yang diberikan latihan fisik maksimal.

\section{METODE}

Penelitian ini menggunakan penelitian eksperimental dengan menggunakan post-test only control group design. Penelitian ini dilakukan di Laboratory Biomedik Terpadu bagian Fakultas Kedokteran Universitas Udayana. Waktu penelitian dilakukan selama 6 bulan dimulai dari bulan Februari sampai dengan bulan Agustus tahun 2019. Subjek yang digunakan dalam penelitian ini adalah tikus putih (Rattus norvegicus) galur wistar yang memenuhi kriteria inklusi, eksklusi dan drop out. Kriteria Inklusi Subjek penelitian yang diinduksi dalam penelitian ini harus memenuhi kriteria inklusi sebagai berikut: tikus jantan wistar sehat, Umur 2-3 bulan dan berat $\pm 200 \mathrm{~g}$. kriteria eksklusi subjek penelitian yang diekslusi dari populasi sampel adalah sebagai berikut: tikus hiperaktif, tikus yang sakit sebelum masa penelitian dimulai dan kriteria drop out subjek penelitian yang di drop out dari populasi sampel adalah sebagai berikut: tikus sakit saat penelitian dan sebelum tiba waktu pengambilan hasil. Teknik penentuan sampel penelitian dilakukan dengan cara berikut : Dari populasi tikus jantan diadakan pemilihan sampel berdasarkan kriteria inklusi, jumlah sampel yang telah memenuhi syarat diambil secara random untuk mendapatkan jumlah sampel, sampel telah dipilih kemudian dibagi menjadi 2 kelompok yaitu kelompok kontrol dan kelompok perlakuan. Dilakukan penelusuran pada karakteristik subjek meliputi jenis latihan 
maksimal, jenis hewan coba, umur, jenis kelamin, berat badan, makanan dan minuman, serta kondisi lingkungan kandang. Analisis data dilakukan dengan bantuan perangkat lunak SPSS versi 16.

\section{HASIL}

Hasil penelitian menunjukan terdapat penurunan rerata kadar MDA dan peningkatan rerata kadar SOD pada tikus wistar jantan yang diberikan latihan fisik maksimal dengan pemberian aquades dan tikus wistar jantan yang diberikan latihan fisik maksimal dengan pemberian ekstrak kubis ungu selama 14 hari, masing-masing dengan urutan mulai dari kelompok kontrol (P0), dan kelompok perlakuan (P1). Pada pemeriksaan kadar MDA kelompok penelitian (P0) memiliki rerata kadar MDA $(1,56 \pm 0,42 \mu \mathrm{M})$ dan kelompok penelitian (P1) memiliki rerata kadar MDA $(1,066 \pm 0,36$ $\mu \mathrm{M})$ sedangkan pada pemeriksaan kadar SOD kelompok (P0) memiliki rerata kadar SOD $(2,94 \pm$ $0,51 \mathrm{ng} / \mathrm{mL}$ ) sedangkan pada kelompok (P1) memiliki rerata kadar SOD $(4,32 \pm 1,11 \mathrm{ng} / \mathrm{mL})$.

Tabel 1. Hasil Analisis Deskriptif Data Variabel Penelitian

\begin{tabular}{|c|c|c|c|c|c|c|}
\hline Variabel & Kelompok & Rerata & SB & Median & Minimum & Maksimum \\
\hline \multirow[t]{2}{*}{$\operatorname{MDA}(\mu \mathrm{M})$} & $\begin{array}{l}\text { Latihan Fisik } \\
\text { Maksimal+ } \\
\text { aquades (P0) (16) }\end{array}$ & 1,56 & 0,42 & 1,63 & 0,67 & 2,38 \\
\hline & $\begin{array}{l}\text { Latihan Fisik } \\
\text { Maksimal + } \\
\text { Ekstrak Kubis } \\
\text { Ungu (P1)(16) }\end{array}$ & 1,06 & 0,36 & 0,99 & 0,47 & 1,75 \\
\hline \multirow[t]{2}{*}{ SOD $(\mathrm{ng} / \mathrm{mL})$} & $\begin{array}{l}\text { Latihan Fisik } \\
\text { Maksimal + } \\
\text { Plasebo (P0)(16) }\end{array}$ & 2,94 & 0,51 & 3,02 & 1,96 & 3,79 \\
\hline & $\begin{array}{l}\text { Latihan Fisik } \\
\text { Maksimal + } \\
\text { Ekstrak Kubis } \\
\text { Ungu (P1)(16) }\end{array}$ & 4,32 & 1,11 & 3,77 & 2,92 & 6,37 \\
\hline
\end{tabular}

Variable kadar MDA dan kadar SOD pada masing masing kelompok (P0) dan (P1) diuji distribusinya dengan menggunakan uji ShapiroWilk. Signifikasi hasil analisis data berpedoman pada tingkat kepercayaan $95 \%(\alpha=0,05)$. Hasilnya menunjukan bahwa data estimasi kadar MDA dan kadar SOD pada masing-masing kelompok berdistribusi normal $(\mathrm{p}>0,05)$ sehingga asumsi pertama analisis data penelitian telah terpenuhi.

Tabel 2. Hasil Uji Normalitas Data Antar Kelompok

\begin{tabular}{clccc}
\hline \multicolumn{1}{c}{ Variabel } & \multicolumn{1}{c}{ Kelompok } & $\mathrm{n}$ & $\mathrm{p}$ & Keterangan \\
\hline MDA $(\mu \mathrm{M})$ & $\begin{array}{l}\text { Latihan Fisik } \\
\text { Maksimal + Plasebo } \\
\text { (P0)(16) }\end{array}$ & 16 & 0,92 & Normal \\
& $\begin{array}{l}\text { Latihan Fisik } \\
\text { Maksimal + Ekstrak } \\
\text { Kubis Ungu } \\
\text { (P1)(16) }\end{array}$ & 16 & 0,72 & \\
& $\begin{array}{l}\text { Normal } \\
\text { Latihan Fisik } \\
\text { Maksimal + Plasebo } \\
\text { (P0)(16) }\end{array}$ & 16 & 0,83 & \\
\hline SOD (ng/mL) & & & Normal \\
& $\begin{array}{l}\text { Latihan Fisik } \\
\text { Maksimal + Ekstrak } \\
\text { Kubis Ungu } \\
\text { (P1)(16) }\end{array}$ & 16 & 0,06 & Normal \\
\hline
\end{tabular}


Variable kadar MDA dan kadar SOD pada masing masing kelompok (P0) dan (P1) diuji distribusinya dengan menggunakan uji Levene's statistic. Hasilnya menunjukan bahwa hanya varian data kelompok kadar MDA saja yang homogen $(\mathrm{p}>0,05)$ dan kelompok kadar SOD tidak homogen $(\mathrm{p}<0,05)$.

Tabel 3. Hasil Uji Homogenitas Data Antar Kelompok

\begin{tabular}{cccc}
\hline Variabel & $\mathrm{N}$ & $\mathrm{p}$ & Keterangan \\
\hline MDA $(\mu \mathrm{M})$ & 32 & 0,837 & Homogen \\
SOD $(\mathrm{ng} / \mathrm{mL})$ & 32 & 0,001 & Tidak Homogen \\
\hline
\end{tabular}

Analisis komparabilitas bertujuan untuk membandingkan rerata estimasi kadar MDA dan kadar SOD antara kelompok tikus wistar jantan yang diberikan latihan fisik maksimal dengan pemberian aquades (P0) dan tikus wistar jantan yang diberikan latihan fisik maksimal dengan pemberian ekstrak kubis ungu (P1) selama 14 hari. Analisa kemaknaan untuk kedua variable diuji dengan Independent Sampel t-test.

Rerata jumlah kadar MDA pada kelompok (P0) setelah diberikan latihan fisik maksimal dengan pemberian aquades selama 14 hari adalah $(1,56 \pm 0,42 \mu \mathrm{M})$, sedangkan pada kelompok (P1) yang diberikan latihan fisik maksimal dengan pemberian ekstrak kubis ungu memliki nilai rerata $(1,06 \pm 0,36 \mu \mathrm{M})$. Analisis kemaknaa dengan Independent Sampel t-test menunjukan bahwa nilai $\mathrm{t}=3,57$ dan nilai $\mathrm{p}=0,001$. Hal ini menunjukan bahwa kelompok perlakuan (P1) memiliki rerata jumlah kadar MDA yang lebih rendah secara bermakna dibandingkan dengan kelompok control (P0) berarti $(\mathrm{p}<0,05)$.

Tabel 4. Hasil Uji Independent Sampel t-test Kadar MDA Antar Kelompok

\begin{tabular}{lccc}
\hline \multicolumn{1}{c}{ Kelompok Subjek } & $\mathrm{n}$ & $\begin{array}{c}\text { Rerata Jumlah } \\
\text { Kadar MDA }(\mu \mathrm{M})\end{array}$ & $\mathrm{P}$ \\
\hline $\begin{array}{l}\text { Latihan Fisik } \\
\text { Maksimal + Plasebo }\end{array}$ & 16 & $1,56 \pm 0,42$ & 0,001 \\
(P0) & & & 3,577 \\
$\begin{array}{l}\text { Latihan Fisik } \\
\text { Maksimal + Ekstrak }\end{array}$ & 16 & $1,06 \pm 0,36$ & \\
Kubis Ungu (P1) & & & \\
\hline
\end{tabular}

Rerata jumlah kadar SOD pada kelompok (P0) setelah diberikan latihan fisik maksimal dengan pemberian aquades selama 14 hari adalah $(2,94 \pm 0,15 \mathrm{ng} / \mathrm{mL})$, sedangkan pada kelompok (P1) yang diberikan latihan fisik maksimal dengan pemberian ekstrak kubis ungu memliki nilai rerata $(4,32 \pm 1,11 \mathrm{ng} / \mathrm{mL})$. Analisis kemaknaa dengan
Independent Sampel T-test menunjukan bahwa nilai $\mathrm{t}=-4,507$ dan nilai $\mathrm{p}=0,000$. Hal ini menunjukan bahwa kelompok perlakuan (P1) memiliki rerata jumlah kadar SOD yang lebih tinggi secara bermakna dibandingkan dengan kelompok control (P0) berarti $(\mathrm{p}<0,05)$.

Tabel 5. Hasil Uji Independent Sampel t-test Kadar SOD Antar Kelompok

\begin{tabular}{lccc}
\hline Kelompok Subjek & $\mathrm{n}$ & $\begin{array}{c}\text { Rerata Jumlah } \\
\text { Kadar SOD } \\
(\mathrm{ng} / \mathrm{mL})\end{array}$ & $\mathrm{p}$ \\
\hline $\begin{array}{l}\text { Latihan Fisik } \\
\text { Maksimal + Plasebo } \\
\text { (P0) }\end{array}$ & 16 & $2,94 \pm 0,15$ & \\
& & & $-4,507$ \\
$\begin{array}{l}\text { Latihan Fisik } \\
\text { Maksimal + Ekstrak }\end{array}$ & 16 & $4,32 \pm 1,11$ & \\
Kubis Ungu (P1) & & & \\
\hline
\end{tabular}




\section{PEMBAHASAN}

\section{Pemberian Ekstrak Etanol Kubis Ungu (Brassicaoleraceavar. capitata L) dapat Menyebabkan kadar Malondialdehyde (MDA) menjadi Rendah}

Ketika melakukan pelatihan fisik yang cukup berat, terjadi peristiwa iskemia-reperfusi yang dapat meningkatkan produksi radikal bebas, dimana peningkatan pasokan oksigen (oxygen supply) sering kali tidak mampu memenuhi kebutuhan oksigen (oxygen demand), fenomena ini disebut sebagai fase iskemia. Sementara itu peningkatan pasokan oksigen yang tinggi justru akan meningkatan pembentukan radikal bebas oksigen bahkan bisa mencapai 10x lipat; fenomena ini disebut fase reperfusi. Beberapa penelitian telah membuktikan bahwa pelatihan fisik berlebih dapat menyebabkan stres oksidatif dimana produksi radikal bebas oksigen meningkat secara bermakna (Tanskanen, 2010)

Semua makhluk hidup, kecuali yang bersifat anaerobik memerlukan oksigen untuk menghasilkan energi secara efisien. Oksigen merupakan komponen yang sangat penting dari metabolisme sel. Reaksi oksidasi terjadi setiap saat di dalam tubuh. Segala aktifitas tubuh kita, termasuk latihan fisik, bahkan ketika kita bernafas, pun terjadi reaksi oksidasi. Namun walaupun sangat dibutuhkan, oksigen dapat pula bersifat toksik yang memicu terbentuknya Reactive Oxygen Species (ROS) yang bersifat sangat reaktif terhadap sel dan komponen sel (Kiyatno 2009). Sekitar 25\% dari oksigen yang dikonsumsi selama metabolisme mitokondria pada organisme aerobik akan menjadi radikal bebas (Berzosa.,et al., 2011).

Kaitan radikal bebas dengan latihan fisik adalah bahwa pada saat seseorang melakukan latihan fisik konsumsi oksigen akan meningkat. Selama latihan fisik konsumsi oksigen meningkat karena peningkatan kebutuhan energi di berbagai jaringan, khususnya pada otot yang berkontraksi. Peningkatan konsumsi oksigen ini menyebabkan peningkatan produksi radikal bebas dan Reactive Oxygen Species (ROS) (Powers.,et al., 2010). Selain itu pada latihan fisik berat, darah yang menuju ke organ-organ yang tidak aktif misalnya hepar, ginjal, lambung dan usus dialihkan ke otototot yang aktif (tungkai dan jantung). Hal ini menyebabkan terjadinya kekurangan oksigen (hipoksia) secara akut pada organ- organ tersebut.

Saat latihan fisik dihentikan, darah akan dengan cepat mengalir kembali ke organ-organ tersebut, dan hal ini dikaitkan dengan terbebaskannya oksidan dalam jumlah besar dari organ-organ tersebut yang sebelumnya mengalami kekurangan oksigen. Radikal bebas itu sendiri adalah atom atau molekul (kumpulan atom) yang memiliki elektron tidak berpasangan pada orbit terluarnya (Winarsi, 2007). Adanya elektron yang tidak berpasangan menyebabkan senyawa tersebut sangat reaktif mencari pasangan, dengan cara menyerang atau mengikat elektron molekul lain yang berada disekitarnya, sehingga terbentuk radikal bebas baru. Radikal bebas berdiri sendiri hanya dalam periode waktu yang sangat singkat, karena ia akan segera menyatu dengan atom lain, (Winarsi, 2007).

Radikal bebas sangat reaktif dan dengan mudah menjurus ke reaksi yang tidak terkontrol, menghasilkan ikatan silang (crosslink) pada DNA, protein, lipida, atau kerusakan oksidatif pada gugus fungsional yang penting pada biomulekulnya (Silalahi, 2006). Mekanisme kerusakan sel atau jaringan akibat serangan radikal bebas yang paling awal diketahui dan terbanyak diteliti adalah peroksidasi lipid. Peroksidasi lipid paling banyak terjadi di membran sel, terutama asam lemak tidak jenuh yang merupakan komponen penting penyusun membran sel. Membran sel kaya akan sumber poly unsaturated fatty acid (PUFA), yang mudah dirusak oleh bahan-bahan pengoksidasi, proses tersebut dinamakan peroksidasi lemak. Hal ini sangat merusak karena merupakan suatu proses berkelanjutan.

Malondialdehyde (MDA) adalah salah satu hasil dari peroksidasi lipid yang disebabkan oleh radikal bebas selama latihan fisik maksimal atau latihan daya tahan (endurance) dengan intensitas tinggi (Wang et al., 2008, sehingga Malondialdehid (MDA) merupakan indikator umum yang digunakan untuk menentukan jumlah radikal bebas dan secara tidak langsung menilai kapasitas oksidan tubuh (Liang et al., 2008). Membran sel sangat penting bagi fungsi reseptor dan fungsi enzim, sehingga terjadinya peroksidasi lipid membran sel oleh radikal bebas yang dapat mengakibatkan hilangnya fungsi seluler secara total (Sinaga, 2016).

Hasil penelitian menunjukan bahwa rerata jumlah kadar MDA pada kelompok kontrol (P0) setelah diberikan latihan fisik maksimal dengan pemberian placebo selama 14 hari memiliki nilai rerata yang lebih tinggi yaitu $(1,56 \pm 0,42 \mu \mathrm{M})$. Hal ini berarti bahwa tikus sudah berada pada kondisi stres oksidatif. Terjadi peningkatan kadar MDA pada plasma dikarenakan tingginya aktivitas yang dilakukan setiap hari selama 14 hari, hal ini mengakibatkan terjadinya ketidakseimbangan antara jumlah antioksidan dan radikal bebas di dalam tubuh. Jumlah antioksidan akan sangat dipengaruhi oleh jumlah radikal bebas yang 
terbentuk di dalam tubuh selama aktivitas fisik tinggi (Baghaiee et al,. 2016). Hasil penelitian ini sejalan dengan penelitian sebelumnya yang dilakukan oleh Arsana bahwa pada kelompok dengan aktivitas fisik yang berlebih memiliki ratarata kadar MDA paling tinggi (Arsana, 2014). Penelitian Rosidi juga menyatakan bahwa terjadi peningkatan kadar MDA setelah aktivitas fisik (Rosidi, 2013).

Hasil penelitian menunjukan bahwa setelah pemberian ekstrak kubis ungu (Brassica oleraceavar. capitata L.) kadar MDA pada kelompok perlakuan (P1) yang diberikan latihan fisik maksimal dengan pemberian ekstrak kubis ungu memiliki nilai rerata $(1,06 \pm 0,36 \mu \mathrm{M})$ yang lebih rendah. Hal ini menunjukkan bahwa pemberian ekstrak kubis ungu (Brassica oleraceavar. capitata $L$.)dapat menurunkan kadar MDA yang meningkat akibat latihan fisik maksimal. Hasil skrining fitokimia pada simplisia dan ekstrak etanol kubis ungu yang dilakukan di Pusat Penelitian Biologi-LIPI Bogor menunjukan bahwa ekstrak kubis ungu mengandung senyawa flavonoid, glikosida, dan antrakinon (Harahap, 2016).

Flavonoid adalah salah satu Kandungan yang dapat meredam efek buruk radikal bebas, dengan menghambat peroksidasi lipid melalui aktivasi peroksidase. Flavonoid yang diisolasi dari kubis ungu dapat melindungi membran phospholipid FUPA dengan menyumbangkan atau memberikan salah satu ion Hidrogennya $(\mathrm{H}+)$ kepada peroksil lipid radikal (LOO*). LOO* merupakan hasil reaksi $\mathrm{HO}^{*}$ pada proses peroksidasi lipid rekasi serangan $\mathrm{HO}^{*}$ terhadap PUFA (PolyUnsaturated Fatty Acid / asam lemak tak jenuh jamak rantai panjang) Pemberian $\mathrm{H}^{*}$ oleh suatu antioksidan dapat menghentikan reaksireaksi radikal selanjutnya sehingga menjadikan radikal yang kurang reaktif (Hamid, 2010).

\section{Pemberian Ekstrak Etanol Kubis Ungu (Brassica oleraceavar. capitata L.) dapat Menyebabkan kadar Superoksida Dismutase (SOD) menjadi Tinggi}

Secara alami tubuh mempunyai kemampuan untuk menangkal radikal bebas dengan membentuk antioksidan endogen yang dihasilkan oleh tubuh yang kadarnya dapat diukur melalui GPx (Glutation Peroxidase), katalase dan aktivitas enzim SOD (Superoxide Dismutase). Superoksida Dismutase adalah enzim yang mengkatalisis dismutasi anion superoksida menjadi hidrogen peroksida $\left(\mathrm{H}_{2} \mathrm{O}_{2}\right)$ dan $\mathrm{O}_{2}$. Meskipun radikal superoksid tidak begitu toksik, namun dapat menarik elektron dari membran sel atau komponen sel lainnya dan menyebabkan reaksi radikal berantai. Radikal superoksida memiliki kemampuan untuk berpartisipasi dalam pembentukan radikal hidroksil (Mittler, 2017). Hidrogen peroksida, setelah terbentuk juga harus dikeluarkan untuk mencegah pembentukan radikal hidroksil. Katalase dan Glutation peroksidase merubah hidrogen peroksida menjadi air (Mittler, 2017) Aktivitas fisik yang terlalu tinggi akan mengakibatkan kadar radikal bebas dalam tubuh juga meningkat sehingga antioksidan endogen tidak mampu untuk menetralisir radikal bebas, dibutuhkan antioksidan eksogen dalam jumlah yang lebih banyak untuk menetralisir efek radikal bebas (Astuti 2008).

Hasil penelitian menunjukan bahwa rerata jumlah kadar SOD pada kelompok kontrol (P0) setelah diberikan latihan fisik maksimal dengan pemberian aquades selama 14 hari memiliki nilai rerata yang lebih rendah yaitu $(2,94 \pm 0,15 \mathrm{ng} / \mathrm{mL})$. Dibandingkan dengan kelompok (P1) perlakuan yang diberikan latihan fisik maksimal dengan pemberian ekstrak kubis ungu memiliki nilai rerata kadar SOD yang lebih tinggi yaitu $(4,32 \pm 1,11$ $\mathrm{ng} / \mathrm{mL}$ ). Hal ini menunjukkan bahwa pemberian ekstrak kubis ungu (Brassica oleraceavar. capitata L.) dapat menurunkan kadar MDA yang meningkat akibat latihan fisik maksimal dan meningkatkan kadar SOD yang menurun akibat pelatihan fisik maksimal.

Hasil penelitian yang dilakukan Tarnajaya (2018) bahwa menyatakan bahwa flavonoid dapat meningkatkan aktivitas SOD dan katalase yang bertanggung jawab atas penurunan tingkat produk peroksidasi lipid seperti MAD, hidroperoksida, dan diena terkonjugasi. Kandungan flavonoid dapat meredam efek buruk radikal bebas, dengan menghambat peroksidasi lipid melalui aktivasi peroksidase terhadap hemoglobin, yang merupakan antioksidan endogen (enzimatik) seperti SOD dan katalase.

Peroksidase bermanfaat untuk mencegah penimbunan $\mathrm{H}_{2} \mathrm{O}_{2}$, yang keberadaannya menjadi berbahaya jika bersama-sama $\mathrm{O}_{2}^{-}$karena dapat membentuk radikal $\mathrm{OH}^{-}$yang merupakan radikal bebas paling reaktif dan paling berbahaya, yang dapat merusak membran sel dengan menyebabkan terputusnya asam lemak tidak jenuh. Flavonoid berperan dalam peningkatan aktivitas enzim SOD dengan mekanisme kerja secara langsung dan tidak langsung. Secara langsung, adanya gugus hidroksil memungkinkan flavonoid untuk menangkap radikal bebas dengan cara menyumbangkan atom hidrogen kepada radikal bebas serta mengkhelat logam yang berperan dalam pembentukan ROS. Secara tidak langsung, flavonoid mampu 
meningkatkan ekspresi gen antioksidan endogen melalui beberapa mekanisme seperti melalui aktivasi nuclear factor erythroid 2 related factor 2 (Nrf2) dengan cara mengaktifkan ekstracelular signal regulated protein kinase (ERK), c-jun nterminal kinase (JNK) dan p38 yang merupakan kinase berperan dalam fosfolrisasi nuclear factor erythroid 2 related factor 2 (Nrf2) dan meningkatkan kadar nuclear factor erythroid 2 related factor 2 (Nrf2) disitoplasma selanjutnya nuclear factor erythroid 2 related factor 2 (Nrf2) terakumulasi di sitoplasma dapat bertranslokasi kedalam nucleus dan berikatan dengan antioksidan responsive elemen (ARE) sehingga mengaktifkan transkripsi gen antioksidan endogen seperti SOD, HO-1 dan NQO1 sehingga terjadi peningkatan dalam sintesis enzim SOD (Sumardika dan Jawi, 2012).

Penelitian ini dilakukan secara in vivo artinya hanya melihat secara umum dari pemberian kubis ungu dapat menyebabkan kadar malondialdehyde (MDA) menjadi rendah dan kadar superoksida dismutase (SOD) menjadi tinggi yang hanya dilakukan pada tikus galur wistar jantan yang diberikan latihan fisik maksimal.

\section{SIMPULAN}

Pemberian ekstrak etanol kubis ungu (Brassica oleraceavar. capitata L.) $1000 \mathrm{mg} / \mathrm{kg}$ BB dapat menyebabkan kadar malondialdehid (MDA) menjadi rendah pada tikus galur wistar jantan (Rattus norvegicus) yang diberi latihan fisik maksimal selama 14 hari. Pemberian ekstrak etanol kubis ungu (Brassica oleraceavar. capitata L.) $1000 \mathrm{mg} / \mathrm{kg}$ BB dapat menyebabkan kadar superoksida dismutase (SOD) menjadi tinggi pada tikus galur wistar jantan (Rattus norvegicus) yang diberi latihan fisik maksimal selama 14 hari

\section{UCAPAN TERIMA KASIH}

Penulis mengucapkan terimakasih kepada seluruh dosen dan rekan-rekan yang telah membimbing dan membantu selama penelitian berlangsung.

\section{DAFTAR PUSTAKA}

Abbott, N.J.; Friedman, A. 2012. Overview and introduction: the blood brain barrier in health and disease. Journal of Epilepsia, Vol 53 no 6 hal 1-6.
Akhlaghi, M., Brian, B. 2009. Mechanisms of flavonoid protection against myocardial ischemia-reperfusion injury. Journal of Molecular and Cellular Cardiology, 46 : 309-17.

Anonim. 2012. Mengetahui Radikal Bebas dan Tipsnya, http://mrsupel.blogspot.com/2012/06/me ngetahui-radikal-bebas-dan-tipsnya.html, diakses tanggal 19 Agustus 2019

Aseervatham, GS; Sivasudha, T; Jeyadevi, R; Arul-Ananth, D. 2013. Environmental factors and and unhealthy lifestyle influence oxidative stress in humans-an overview. International Journal of Environmental Science and Pollution Research. Vol 20(7):4356-69. doi: 10.1007/s11356-013-1748-0.

Astuti S. 2008. Isoflavon kedelai dan potensinya sebagai penangkap radikal bebas. Jurnal teknologi industry dan hasil pertanian Universitas Lampung 13(2):126-136.

Ayala A, Muñoz MF, Argüelles S. 2014. Lipid Peroxidation: Production, Metabolism, and Signaling Mechanisms of Malondialdehyde and 4- Hydroxy-2Nonenal. Oxidative Medicine and Cellular Longevity. Oxidative Medicine and Cellular Longevity. 2014:360438. doi:10.1155/2014/360438.

Baghaiee B, Aliparasti ML, Almasi S, Siahkuihan M, Baradaran B. 2016. Antioxidant expression response to free radicals in active men and women fallowing to a session incremental exercise; Numerical relationship between antioxidants and free radicals. Asian J Sport Med 7(2). doi: 10.5812/asjsm.29901.

Bayu, A. 2009. Hutan Mangrove Sebagai Salah Satu Sumber Produksi Alam Laut. Oseana. Vol. XXXIV No.2 : 15-23

Birke, L. 2014. Escaping the Maze: Wildness and Tameness in Studying Animal Behaviour, in Marvin, G., McHugh, s., editors. RoutledgeHandbook of Human Animal Studies. New York: Routledge. P. 39-53

Berzosa C et al., 2011. Acute ExerciseIncrease Plasma Total AntioxidantStatus 
andAntioxidant EnzymeActivities in Untrained Men. Journal of Biomeicine and Biotechnology.

Chevion, S., Molan, DS., Heled Y. 2003. Plasma antioxidant status and cell injury after severe physical exercise. PNAS. 100(9):5119-23

Choi, S.W., Son, B.W., Son, Y.S., Park, Y. I., Lee, S. K., Chung, M. H. 2001. The woundhealing effect of a glycoprotein fraction isolated from Aloe vera. British Journal of Dermatology. Vol: 145, No. 4. P. 535-545

Damayanthi, E. 2010. Aktivitas Antioksidan Bekatul Lebih Tinggi Daripada JusTomat dan Aktivitas Antioksidan Serum Setelah Intervensi Minuman Kaya Antioksidan. jurnal Gizi dan Pangan, 5 (3): 205-210 .

Darmono, S. 2011. Buku Ajar Farmokologi Eksperimental. Jakarta: Universitas Indonesia. Hal: 1-2

Dalimartha, S. 2000. Atlas Tumbuhan Obat Indonesia. Jilid Kedua. Jakarta: Trubus Agriwidya. Halaman 116 - 119.

Daud, M.A., Sanjana, R., Shahnaz, R., Ishtiaq, A., dan Mohammed, R. (2015). How Good is Red Cabbage Extract for Lowering High Blood Glucose and Alleviating Pain? A Preliminary Evaluation of Brassica oleracea $\mathrm{L}$. var capitata f. rubra. World Journal of Pharmacy and Pharmaceutical Sciences. 4(9): 1642 - 1651.

Erukainure, O.L., Oke,O.V., Ajiboye, A.I., Okafor ,O.Y. 2011. Nutritional and Phytochemical Constituents Of Clerodendrum Volubile, a Tropical Nonconventional Vegetable. International Food Research Journal, 18(4) : 13931399.

Gibney, M.J. 2009. Gizi Kesehatan Masyarakat. Jakarta EGC.

Goodsell, D. 2007. Molecule of the Month: Superoxide Dismutase. http://www.rcsb.org/pdb/static.do?p=edu cation_discussion/molecule_of_the_mont h/ pdb94_1.htm, diakses tanggal 27 Oktober 2012.
Grassi D., Giovambattista Desideri and Claudio Ferri. 2010. Flavonoids: Antioxidants Against Atherosclerosis. Nutrients. 2: 889-902.

Hairrudin. 2005. Pengaruh Pemberian Ekstrak Jinten Hitam Dalam Mencegah Stres Oksidatif Akibat Latihan Olahraga Anaerobik. Jurnal Biomedis III, (1) :1-11.

Halliwell, B. and Gutteridge, J. M. C. (2007). Free Radicals in Biology and Medicine. Oxford: Oxford University Press dalam Henry, J. 2014. Advances in Food and Nutrition Research. Volume 71-Academic Press

Hamid AA., Aiyelaagbe, O.O., Usman, L.A., Ameen, O.M. and Lawal, A. 2010. Antioxidants: Its medicinal and pharmacological applications. African $J$. of Pure and Applied Chemistry. 4(8):14251.

Han, X., Shen, T., and Lou, H. 2007. Dietary Polyphenol and Their Biological Significance. Int.J.Mol.Sci, 8: 950-988.

Harahap N.S. 2008. Pengaruh Aktifitas Fisik Maksimal Terhadap Jumlah Leukosit Dan Hitung Jenis Leukosit Pada Mencit (Mus Musculus L) Jantan. Medan: USU eropository.

Harahap, N.K. 2016. "Karakter Simplisia dan Uji Toksisitas Subkronik Ekstrak Etanol Kubis Ungu (Brassica Oleracea L. Var. Cavitata F. Rubra)" (Skripsi). Medan : Universitas Sumatra Utara.

Harjanto, 2004. Pemulihan Stres Oksidatif Pada Latihan Olahraga. Jurnal Kedokteran YASRI 12 (3) : 81-87

Harmita. 2006. Buku Ajar Analisis Hayati Edisi III. Penerbit Buku Kedokteran ECG. Jakarta.

Hidayat, N., Padaga, M.C., Suhartini, S. 2006. Mikrobiologi Industri. Yogyakarta : Andi Offset.

Hu JP, Zhao XP, Ma XZ, Wang Y, Zheng LJ. 2014. Effects of cigarette smoke on aerobic capacity and serum MDA content 
and SOD activity of animal. Int J ClinExp Med, 7(11): 4461-4465.

Irianti, E. 2008. Pengaruh Aktifitas Sedang Terhadap Hitung Leukosit dan Hitung Jenis Sel Leukosit Pada Orang Tidak Terlatih. Medan: USU e-ropository.

Islam, E., Mahbubur R., Kudrot-e-azam, Shahnaz R., Shahadat H., dan Mohammed R.. (2015). Oral Glucose Tolerance Test, Phytochemical Screening and Acute Toxicity Studies with Methanolic Extract of Red Cabbage Leaves. Journal of Chemical and Pharmaceutical Research.7(4):658-661.

Johnson, M. 2012. Laboratory Mice and Rats. Mater Methods 2:113. http://www.labome.com/method/Laborat ory-Mice-and-Rats.html.Diakses 19 Agustus 2019.

Karadeniz, F., Hande, S.B., Nuray, K.,Yeflim, S. 2005. Antioxidant Activity of Selected Fruits and Vegetables Grown in Turkey. Turkey: Ankara University.

Khasan.2015. "Pengaruh Pemberian Antioksidan Vitami C Pada Latihan Fisik Maksimal Terhadap Penurunan Stres Oksidatif Tikus Putih Stain Wistar" (skripsi). Semarang: Fakultas Ilmu Keolahragaan Universitas Negeri Semarang.

Kiyatno. 2009. Antioksidan Vitamin dan Kerusakan Otot Pada Aktivitas Fisik Studi Eksperimen Pada Mahasiswa JPOK-FKIP UNS Surakarta. MMed Indonesia.; 6(43).

Kusumawati, D. 2004. Bersahabat Dengan Hewan Coba. Yogyakarta: Gadjah Mada University Press.

Kumar, B., Sandhar, H.K., Tiwari, P, Salhan, M., Sharma, P. 2011. A Riview Of Phytochemistry and Pharmacology Of Flavonoid. International Pharmaceutica Sciencia (IPS) 1(1): 26-29

Lee, N., Koo, N., Min, D.B. 2004. Reactive oxygen species, aging, and antioxida tivenutraceuticals. Comprehensive reviews in food science and food safety 3 : 21-33
Liang Y, Fang J.Q, Wang C.X, Ma G.Z .2008.. Effects of transcutaneous electric acupoint stimulation on plasma SOD and MDA in rats with sports fatigue. Zhen Ci Yan Jiu, 33: $120-123$.

Lima VR, Morfim MP, Teixeria A, Crecszynski TB. 2004. Relationship between the action of reactive oxygen and nitrogen species on bilayer membranes and antioxidants. Chemistry and physics of lipids, 132: 197208

Lin, W., Wu, R.T., Wu, T., Khor, T.-O., Wang, H., dan Kong. 2008. Sulforaphane suppressed LPS-induced inflammation in mouse peritonea macrophages through Nrf2 dependent pathway. Biochemical pharmacology, 76: 967-973.

Majeed, M.S. (2004). Effect of Red Cabbage Extract on Oxidative Stress and Some Cytokines Levels in Hyperthyroid Rabbits Induced by Thyroxine. Ministry of Higher Education and Scientific Research University of Baghdad. 23(1): 28-29.

Mark, D., Mark, A., Smith, C. Biokimia Kedokteran Dasar, Sebuah Pendekatan Klinis. P 321- 33

Mc. Cord J.M., Fridovich I. 2006. Superoxide dismutase. An enzymic function for erythrocuprein (hemocuprein). J.Biol Chem.244(22):6049-55.

Mittler, R. 2017. ROS Are Good. Trends in Plant Science, January 2017, Vol. 22, No.1.

Muchtadi, D. 2013. Antioksidan Kiat Sehat di Usia Produktif. Bandung: Penerbit Alfab-eta

Murray R. K., Granner D.K., Rodwell V.W., 2009. Biokimia Harper, (Andri Hartono). Edisi 27. Penerbit Buku Kedokteran, EGC. Jakarta.

Nanik Lidyawati Sugianto. 2011. "Pemberian Jus Delima Merah (Punica Granatum) Dapat Meningkatkan Kadar Glutation Peroksidase Darah Pada Mencit (Mus Musculus) Dengan Aktifitas Fisik Maksimal". Tesis. Program Pascasarjana Universitas Udayana Denpasar 
Neeflufar. S., Alekhya, T. and Sudhakar, K. 2012, Pharmacognostical and Phytochemical evaluation of BrasiccaOleracea Linn Var. Capitata F. Rubra (The Red Cabbage), $J$. pharma bio, 2(2): 43-46.

Negre, S.A., Coatrieux, C., Ingueneau, C., Salvayre, R. 2008. Advanced Lipid Peroxidation end Products in Oxidative Damage to Proteins. Potential Role in Diseases and Therapeutic Prospects For The Inhibitors. British Journal of Pharmacology. 153 (1): 6-20.

Pamungkas, D. 2016. Pengujian Aktivitas Antioksidan Penetapan Kadar Fenol Total Kombinasi Ekstrak Metanol Daun Mangga Gadung (Mangifera indica L.var gadung) dan Ekstrak Etanol daun Pandan Wangi (Pandanusamary llifolius roxb). Jawa Barat: Fakultas Farmasi Universitas Jember

Pangkhahila, W. 2007.Memperlambat Penuaan, Meningkatkan Kualitas Hidup. Pillon, NJ., Soulage, CO. 2012. Lipid peroxidation: Lipid peroxidation by products and the metabolic syndrome. Croatia: InTech

Pietta, P.G. (2000). Flavonoids as Antioxidants. $J$ Nat Prod, 63, 1035-42

Powers, S.K., Jackson. 2008. Exercise induced oxidative stress: cellular mechanism and impact on muscle force production. Physiol Rev 88(4): 1243-76

Pratama, M., Aminah., Arfanita, R. 2018. Efektivitas pemanfaatan potensi senyawa kubis ungu (Brassica Olereceae Var. Carpitata. L) [Online] JFFI. 5(2) 293-298.

Putri, R.F., Evi, U.U., Rini, R.. (2014). Uji Aktivitas Anti Platetelet Ekstrak Etanol Kubis Merah (Brassica oleracea var. $\begin{array}{lll}\text { capitata } & \text { L.). } & \text { Pustaka }\end{array}$ Kesehatan.2(11):111-114.

Rohimah, Y.T., Soempeno, B. 2005. Jumlah Leukosit dan Persentase Leukosit Neutropil Pada Latihan Aerobik Tipe High Impact Setelah Pemberian Kombinasi Vitamin C dengan Bioplavonoid "Tesis". Yogyakarta: Universitas Gajah Mada.
Rokayya, S., Chun, J. L., Yan, Z., Ying, L., dan Chang, H. S., (2013).Cabbage (Brassica oleracea L. var. capitata) Phytochemicals with Antioxidant and Anti-inflammatory Potential. Asian Pac J Cancer Prev. 14(11):6657-6662.

Rosidi A. 2013. "Pengaruh pemberian ekstrak temulawak (curcuma xanthorrhiza roxb) terhadap stres oksidatif dan kesegaran jasmani atlet" Disertasi.Bogor: Institut Pertanian Bogor.

Ruchel, JB. 2017. Guarana (Paullinia cupana) ameliorates memory impairment and modulates acetylcholinesterase activity in Poloxamer-407-induced hyperlipidemia in rat brain. Physiol Behav. Vol $168 \mathrm{Hal}$ 11-19. doi: 10.1016/j.physbeh.2016.10.003.

Setiawan, B., Suhartono, E. 2005. Stres Oksidatif dan Peran Antioksidan pada Diabetes Melitus. Maj Kedokt Indon, Volum: 55, Nomor: 87

Shama, S.N., Alekhya, T., danSudhakar, K. 2012.Pharmacognostical\& Phytochemical Evaluation of Brassica oleracea Linn var. capitataf.rubra (The Red Cabbage). Journal of Pharmaceutical Biology. 2(2):45.

Sihombing, M., Tuminah, S. 2011. Perubahan Nilai Hematologi, Biokimia Darah,Bobot Organ dan Bobot Badan Tikus Putih Pada Umur Berbeda. Jurnal Veteriner. Vol : 12 no 1 . Hal : 58-64

Sinaga, F.A. 2016."Stres Oksidatif dan Status Antioksidan Pada Aktivitas Fisik Maksimal" (Tesis). Medan : UNIMED

Simamora, A. 2011. "Flavonoid Dalam Apel dan Aktivitas Anti Oksidannya" (Tesis). Universitas Kristen Krida Wacana

Silaban, L.W. 2009. "Skrining Fotokimia dan Uji Aktivitas Anti Bakteri dan Kulit Buah Sentul (Sandoricum Koetjape (Burm , F) Terhadap Beberapa Bakteri Secara In Vitro" (Skripsi). Medan : Fakultas Farmasi, Universitas Sumatra Utara 
Silalahi, J. 2006. Makanan Fungsional. Yogyakarta : Kanisius

Smith, J.B., Mangkoewidjojo, S. 1998. Pemeliharaan, Pembiakan dan Penggunaan Hewan Percobaan di Daerah Tropis. Jakarta: Universitas Indonesia.

Sumardika, I.W., dan Jawi, I.M. 2012. Ekstrak Air Daun Ubi Jalar Ungu Memperbaiki Profil Lipid dan Meningkatkan Kadar SOD Darah Tikus yang Diberi Makanan Tinggi Kolestrol, Jurnal Ilmiah Kedokteran Medicina 43(2) : 67-71

Surh, Y.J. 2003.Cancer Chemoprevention with Dietary Phytochemicals. Journal of Nature Reviews Cancer, 3, 768-780.

Suryohusodo, P. 2000. Oksidan dan Radikal Bebas. Jakarta: CV Infomedika.

Suryohudoyo. 2005. Oxidant and Anti Oxidant Defense In Healt and Disease. Post Gruduate Program Airlangga University In Collaboration With Institute Of Biochemistry. Hombolt University Berlin Germany. Surabaya. 1-17

Tanskanen M, AtalayM, Uusitalo A. 2010. Altered oxidative stress in overtrained athletes. $J$ Sports Sci.28(3):309-17.

Tarnajaya, K., Pangkahila, A., Pangkahila, W., Siswanto, M. 2018. Pemberian Ekstrak Daun Cincau (Mesonapalustris BL) Meningkatkan Kadar Superoksida Dismutase (SOD) TikusWistar (Rattusnorvegicus) Jantan yang Diinduksi Latihan Fisik Berlebih. Denpasar: Fakultas Kedokteran Universitas Udayana.

Wahyuni. 2008. Kajian kemampuan jus buah tomat (solanumlycopersicum) dalam menghambat peningkatan kadar malondialdehide plasma setelah latihan aerobic tipe high impact. Jurnal kesehatan. Vol.1.NO. 2:123-132.

Wang, L., Zhang, H.L., Zhou, Y.J., Ma, R., Lv, J.Q., Li, X.L., Chen, L.J. and Yao, Z. 2008. The decapeptide CMS001 enhances swimming endurance in mice. Peptides, 29: 1176-1182.

World Health Organization. 2013. Global Strategy on Diet, Physical Activity and Health.

Winarsi, H.2007. Antioksidan Alami dan Radikal Bebas. Yogyakarta: Kanisius

Wistar Institute. 2014. Our History. Philadelphia: The Wistar Institute http://www.wistar.org. Diakses 31 Januari 2019.

Wong, S., Lai, P.L., and Hoe, W.K., 2005, Antioxidant Activities of Aqueous Extracts of Selected Plants, J. Foodchem, Food Science and Technology Programme, Department of Chemistry, Natonal Universitas of Singapore, Singapore.

Wulandari, E. 2016. "Efek Ekstrak Kulit Buah Rambutan Terhadap Kadar MDA dan Aktivitas SOD Pada Tikus Yang Dipapar Asap Rokok" (tesis). Semarang: Fakultas Matematika dan Ilmu Pengetahuan Alam Universitas Semarang.

Yang R-L, Shi Y-H, Hao G, Li W, Le G-W. 2008. Increasing Oxidative Stress with Progressive Hyperlipidemia in Human: Relation between Malondialdehyde and Atherogenic Index. Journal of Clinical Biochemistry and Nutrition. Vol 43(3):154-158. doi:10.3164/jcbn.2008044.

Yavari A, Javadi M, Mirmiran P, Bahadoran Z. 2015. Exercise induced oxidative stress and dietary antioxidants. AJSM 6(1):1-7. doi:10.5812/asjsm.24898. 